\title{
Environmental effects of the discharge of untreated effluent from the potato-flour industry
}

Norbert Dankers (Research Institute for Nature Management (RIN), Texel Branch, P.O. Box 59, 1790 AB Den Burg, Netherlands)

Accepted: 1 June 1984

\begin{abstract}
A pipeline has been planned to discharge organically polluted effluent into the Dollard Estuary. On the basis of information supplied by a computer mod$\mathrm{el}$, large parts of the Dollard would become anaerobic, and this would have severe effects on macrobenthic organisms, and therefore also on foraging birds and fish. Key-words: organic pollution, estuary, oxygen depletion.
\end{abstract}

Introduction. At present large amounts of organically polluted water are discharged into canals and then flow to the Dollard Estuary. Much of the organic matter is broken down in the canals, creating anaerobic conditions and a nauseous smell. Plans exist to relieve the area of the smell problem, and one option is direct discharge into the estuary by pipeline.

Much research has been carried out in the area and, for a description of the expected biological effects, I used the conclusions of a recently published model that predicted the oxygen concentrations in the Dollard for several scenarios of discharge and purification (Ruardij \& van Es, 1983).

Results. For several reasons, it will make a difference whether organic material is discharged directly (by pipeline) or indirectly (through canals).

Effluent discharged into canals takes about 6 weeks to reach the estuary. This means that part of the material is broken down when the water reaches the Dollard Estuary, and the organic compounds still present do not break down easily and therefore spread over a larger part of the estuary before breaking down. Discharge through a pipeline will deliver 'fresh' waste with a high organic load and organic compounds that will break down relatively easily near the outfall.

Because of the long residence time in the canals, effluent reaches the Dollard Estuary by the end of September. However if a pipeline is used, discharge will start in the middle of August, when more animals are still present, and water temperatures are higher (less oxygen).

In their mathematical model, one of the scenarios Ruardij \& van Es (1983) used gave a discharge of 245 t of COD (chemical oxygen demand), of which $75 \%$ was easily degradable and $25 \%$ difficult to degrade, if at all. They concluded that an area of about $80 \mathrm{~km}^{2}$ would have oxygen concentrations of less than $5 \mathrm{mg} / \mathrm{l}$. If the effuent were treated, concentrations of less than $5 \mathrm{mg} / \mathrm{l}$ would occur only in an area of $4 \mathrm{~km}^{2}$. 


\section{N. DANKERS}

Since 1977, the amount of discharged organic matter has decreased considerably. However if the new plans proceed, it can be expected that the oxygen conditions in the Dollard Estuary will be comparable to the 1977 situation.

The polychaete Nereis diversicolor occurs in the Estuary at high densities. The species is highly resistant to extreme environmental conditions. Nevertheless these worms used to disappear in large areas of the Dollard Estuary when discharge started each autumn. When discharge decreased after 1977, Essink et al. (1983) found that the worms were present all the year round. So the main biological effect of direct discharge by pipeline would be the autumn disappearance of the ragworm ( $N$. diversicolor) from an area of $10-40 \mathrm{~km}^{2}$. This means a loss of $13-112 \mathrm{t}$ (ash-free dry weight) of high-quality food for higher organisms. The numbers of avocets ( Recurvirostra avocetta), therefore, may decrease by $15 \%$.

$N$. diversicolor is also eaten by fish, but fish and shrimps are also directly affected by low oxygen concentrations. Mortality of shrimps has been shown regularly when effluent was discharged (Anon., 1983). Also shrimps are an important food source for several species of birds.

\section{References}

Anonymous, 1983. Biologisch onderzoek Eems-Dollard Estuarium. BOEDE Publikaties en Verslagen 1983-1. BOEDE, P.O. Box 59, Den Burg, Netherlands, 267 pp.

Essink, K., H. L. Kleef, W. Visser \& P. Tijdeman, 1983. Population dynamics of the ragworm Nereis diversicolor in the Dollard (Ems estuary) under changing conditions of stress by organic pollution. Proceedings of the 17th European Symposium on Marine Biology (Oslo), in press.

Ruardij, P. \& F. B. van Es, 1983. Berekeningen aan de mogelijke gevolgen voor de zuurstofhuishouding in de Dollard van een persleiding voor afvalwater van de aardappelmeelfabriek in Terapelkanaal naar Nieuw-Statenzijl. BOEDE Publikaties en Verslagen 1983-4. BOEDE, P.O. Box 59, Den Burg, Netherlands, $19 \mathrm{pp}$.

This synopsis is based on a report of the Research Institute for Nature Management entitled 'De milieu-effecten van lozing van ongezuiverd veenkoloniaal afvalwater in de Dollard via een persleiding', 1984. ii +12 pp., 1 figure, 15 refs. Dutch.

Available as paper copy (order R011P, $f 3.50$ including postage) or microfiche (order R011M, f 12.50 including postage) at: NARD, clo Pudoc, P.O. Box 4, 6700 AA Wageningen, Netherlands (telex 45015 blhwg $n l$ ). 